\title{
MENINGKATKAN KETERAMPILAN MENYIMAK MELALUI PENDEKATAN SAINTIFIK PADA ANAK KELAS IV JAKARTA BARAT
}

\author{
Tio Gusti Satria
}

Universitas Negeri Jakarta - tiogustisatria@gmail.com

\begin{abstract}
Abstrak
Penelitian ini bertujuan untuk meningkatkan kemampuan menyimak kelas IV SDN Mangga Besar 01 Pagi, Kecamatan Taman Sari, Jakarta Barat, melalui Pendekatan Saintifik. Penelitian ini merupakan penelitian tindakan dengan menggunakan model Kemmis dan Mc.Taggart, penelitian tindakan ini dilakukan dalam dua siklus. Masingmasing siklus terdiri dari tahap perencanaan, implementasi tindakan, pengamatan, dan refleksi tindakan. Subyek penelitian peserta didik kelas IV SD. Proses pengumpulan data melalui tes hasil belajar dan non tes berupa hasil observasi pelaksanaan pendekatan saintifik, dengan menggunakan lembar observasi aktivitas guru dan siswa, catatan lapangan dan hasil dokumentasi. Hasil penelitian menunjukkan adanya peningkatan kemampuan menyimak. Hal ini dibuktikan dengan rata-rata prosentase siswa pada tindakan siklus I yaitu $55 \%$. Aktivitas guru sesuai langkah-langkah metode ini mencapai $75.6 \%$, dan aktivitas siswa mencapai $70 \%$. Mengalami peningkatan pada siklus II mencapai $93 \%$. Aktivitas guru sesuai langkah-langkah metode ini mencapai 83\%, dan aktivitas siswa mencapai $80.4 \%$. Kesimpulan dari penelitian ini adalah pendakatan saintifik mampu untuk meningkatkan keterampilan menyimak, hal ini terkhusus pada materi ajar tema 5 Pahlawanku, subtema 1 Perjuangan Para Pahlawan, dan subtema 2 Pahlawanku Kebanggaanku. Semua itu tentunya tidak terlepas dari kemampuan masingmasing guru dalam mengkolaborasikan antara pendekatan yang digunakan, bahan ajar, dan media pembelajaran yang digunakan.
\end{abstract}

Kata Kunci: Kemampuan Menyimak, Pendekatan Saintifik, dan Penelitian Tindakan

\section{PENDAHULUAN}

Berdasarkan Permen nomor 57 tahun 2014 tentang kurikulum 2013 Bahasa Indonesia adalah salah satu muatan materi yang masuk kedalam pembelajaran tematik pada Kurikulum 2013. Bahasa Indonesia masuk ke dalam mata pelajaran umum kelompok A yang terdiri dari Pendidikan Agma, Pancasila dan Kewarganegaraan, Bahasa Indonesia, Matematika, IPA, dan IPS. Bahasa Indonesia sebagai penghela mata pelajaran lain. Bahasa memiliki peran yang sangat besar pada kehidupan manusia. Bahasa sebagai suatu cara berkomunikasi sangat mempengaruhi kehidupan individu dimana kita saling bertukar pendapat, ide, dan gagasan. Berdasarkan kenyataan berbahasa, kita lebih banyak berkomunikasi secara lisan dibandingkan dengan cara lain. Lebih dari separuh waktu kita digunakan untuk berbicara dan mendengarkan, dan selebihnya untuk menulis dan membaca.

Keterampilan berbahasa mencakup empat segi, yaitu 1) keterampilan menyimak, 2) keterampilan berbicara, 3) keterampilan mebaca, 4) keterampilan menulis. Setiap keterampilan itu erat sekali hubungannya dengan keterampilan lainnya dengan cara yang beraneka ragam. Dalam memperoleh keterampilan berbahasa, biasanya kita melalui suatu hubungan urutan yang terakhir, mula-mula kita belajar menyimak bahasa kemudian berbicara, sesudah itu kita membaca dan menulis. Menyimak dan berbicara kita pelajari sebelum memasuki 
sekolah, sedangkan membaca dan menulis kita pelajari di sekolah.

Kondisi peserta didik dalam kegiatan menyimak saat ini cukup memprihatinkan, keterampilan menyimak menjadi hal yang tidak diperhitungkan dan tidak tidak dianggap penting dibandingkan dengan keterampilan lainnya. Hal ini didukung oleh pendapat Dadan Djuanda (dalam bukunya pembelajran keterampilan berbahasa Indonesia di sekolah dasar.)

Menurut Dadan Djuanda dalam kegiatan di kelas, menyimak sudah menjadi bagian dari pembelajaran bahasa. Namun dalam praktek pembelajarannya di kelas, menyimak sering tidak dianggap sebagai pembelajaran yang perlu persiapan ataupun direncanakan. Atau, keterampilan menyimak hanya sebagai bagian dari kegaiatan mendengarkan teks bacaan yang dibaca nyaring tanpa persiapan dan penilaain yang terencana. Dengan kata lain, pembelajaran menyimak belum terlaksana dengan maksimal.

Pengamatan yang dilakukan terhadap proses pembelajaran pada tanggal 19 Oktober 2016 menunjukkan bahwa peserta didik kelas IV (empat) SDN 01 Pagi Mangga Besar Kecamatan Taman Sari Jakarta Barat, dalam keterampilan menyimak pada Kompetensi Dasar 3.4 Menggali informasi dari teks cerita petualangan tentang lingkungan dan sumber daya alam dengan bantuan guru dan teman dalam bahasa Indonesia lisan dan tulis dengan memilih dan memilah kosakata baku. Tema 4, Subtema 1, pembelajaran 3, terbukti bahwa peserta didik kurang antusias dalam mengikuti kegiatan pembelajaran, para peserta didik ada yang sibuk dengan aktifitas lain, ada yang pura-pura memperhatikan, da nada yang keluar masuk kelas..

Selanjutnya dalam proses wawancara dengan guru juga menunjukkan hasil yang tidak jauh dengan hasil pengamatan, bahwa peserta didik kelas IV SDN 01 Mangga Besar mengalami kesulitan dalam memahami bahan simakan tentang menggali informasi dari teks cerita petualangan tentang lingkungan dan sumber daya alam. Untuk mengatasi masalah ini dibutuhkan suatu upaya dari guru agar keterampilan menyimak peserta didik dapat meningkat yaitu dengan menggunakan pendekatan saintifik.

Menurut Alfred De Vito di dalam Abdul Majid dan Chaerul Rocman Pembelajaran saintifik merupakan pembelajaran yang mengadopsi langkahlangkah saintis dalam membangun pengetahuan melalui model ilmiah. Model pembelajaran yang diperlukan adalah yang memungkinkan terbudayakannya kecakapan berfikir sains, terkembangnya sense of inquiry, dan kemampuan berfikir kreatif siswa. Sasaran utama dalam pendekatan saintifik adalah para peserta didik yang terlibat aktif dalam pebelajaran karena belajar menyimak bukanlah sekedar kegiatan mendengarkan semata melainkan mengidentifikasi dan menginterpretasi, menilai dan mereaksi atas makna yang terkandung dalam pembelajaran .

Dari paparan tersebut, maka direncanakan suatu penelitian dengan judul "Meningkatkan Kemampuan Menyimak Melalui Penerapan Pendekatan Saintifik pada Siswa Kelas IV SDN 01 Pagi Mangga Besar Kecamatan Taman Sari Jakarta barat".

\section{METODE}

Metode penelitian yang digunakan dalam pelaksanaan penelitian adalah penelitian tindakan kelas (classroom action research) Penelitian ini dilakukan dengan empat tahapan yaitu mulai dari perencanaan, pelaksanaan tindakan, pengamatan tindakan, dan berakhir dengan refleksi. Penelitian ini bermaksud untuk melakukan perbaikan terhadap keterampilan menyimak kelas IV SD menggunakan pendekatan saintifik agar keterampilan menyimak siswa lebih meningkat.

Penelitian dilakukan pada semester genap tahun ajaran 2016/2017. Pelaksanaan penelitian dilakukan terhitung empat bulan di lapangan. Hal ini berkaitan dengan pokok bahasan yang diteliti pada mata pelajaran Bahasa Indonesia dengan tema 5 Pahlawan, 
subtema 1 Perjuangan para Pahlawan, dan subtema 2 Pahlawanku Kebanggaanku. Kompetensi Dasar Bahasa Indonesia Menggali pengetahuan baru yang didapat dari teks nonfiksi

Penelitian dilaksanakan sesuai dengan apa yang tertuang dalam RPP di setiap siklus. Apabila pada siklus pertama belum memperoleh hasil yang diinginkan maka dilanjutkan dengan siklus kedua dengan tindakan berasal dari hasil pengembangan refleksi pada siklus pertama. Pada setiap tindakan dilakukan observasi dan membuat catatan lapangan mengenai kejadian yang tak luput dari lembar pengamatan, untuk memperkuat data sebagai landasan bagi tindakan berikutnya

Data yang diperlukan dalam penelitian ini ada dua yaitu proses pembelajaran dan data hasil pembelajaran keterampilan menyimak mata pelajaran Bahasa Indonesia di kelas IV.

Teknik pengumpulan data yang digunakan untuk mendeskripsikan data kelas ini ada dua yaitu tes dan non tes. Dalam penelitian ini digunakan tes tertulis dalam bentuk obyektif tes.

\section{HASIL}

\section{SIKLUS I}

Setalah terlaksananya kegiatan penelitian siklus I yakni terhitung empat pertemuan, yang dimulai pada hari Selasa tanggal 10 januari 2017 sampai dengan hari Kamis tanggal 19 Januari 2017 dengan tema Pahlawanku, subtema Perjuangan Para Pahlawan, banyak hal yang telah diamati selama penelitian. Aspek yang diamati mencakup aspek ranah kognitif, dan psikomotor. Hal ini akan menjadi bahan evaluasi dan pertimbangan serta perbaikan terhadap masalah yang dihadapi, sebagai sebuah langkah dalam mencari solusi untuk memperbaiki keterampilan menyimak siswa.

Berdasarkan hasil penilaian yang dilakukan oleh observer (Jamsiah,S.Pd) terhadap peneliti sebagai pendidik dalam pembelajaran Bahasa Indonesia yang dilaksanakan selama siklus I aktivitas pembelajaran yang dilakukan oleh peneliti sebagai pendidik mendapatkan nilai dengan persentasi $75,6 \%$.

Sementara untuk hasil pengamatan yang dilakukan oleh observer (Jamsiah, S.Pd) terhadap peserta didik dalam pembalajaran Bahasa Indonesia yang dilaksanakan selama siklus I, aktivitas pembelajaran yang dilakukan oleh peserta didik mendapatkan nilai dengan presentasi $70 \%$.

\section{Ranah Kognitif}

Tahap akhir pembelajaran pada siklus I, peneliti mengadakan tes tertulis untuk mengukur perkembangan kognitif siswa terhadap peningkatan keterampilan menyimak pada pembelajaran Bahasa Indonesia dengan menggunakan pendekatan saintifik. berdasarkan hasil tes tersebut diketahui seberapa besar perkembangan peserta didik dalam memahami materi mengenal arti kepahlawnan.

Melihat daftar nilai pada tabel hasil tes kognitif pada siklus terdapat 29 siswa yang mengikuti tes, terdapat dua siswa (7\%) yang meraih nilai kisaran 85-100 (Peringkat A), empat belas siswa (48\%) yang meraih nilai kisaran 70-84 (Peringkat B), dua siswa (7\%) yang meraih nilai kisaran 55-69 (Peringkat C), dan sebelas siswa (38\%) yang meraih nilai kurang dari 55 (Peringkat D).. Berikut ini adalah tabel perbandingan untuk memperjelas hasil belajar yang diraih siswa pada siklus I

Tabel 4.3 Perbandingan hasil belajar ranah kognitif siklus I

$\begin{array}{lcc}\text { Hasil } & \text { Banyak } & \text { Presentase } \\ \text { Belajar } & \begin{array}{c}\text { Peserta } \\ \text { Didik }\end{array} & \\ & \end{array}$

\begin{tabular}{ccc} 
Tuntas & 16 & $55 \%$ \\
\hline $\begin{array}{c}\text { Belum } \\
\text { Tuntas }\end{array}$ & 13 & $45 \%$ \\
\hline Jumlah & 29 & $100 \%$
\end{tabular}

\section{Ranah Psikkomotor}


Penilaian ranah psikomotor yang dilakukan oleh peneliti terhadap peserta didik pada siklus I menggunakan tes tertulis, hal ini bertujuan untuk menguji keterampilan siswa dalam menyimak pada pemebelajaran bahasa Indonesia dengan menggunakan pendekatan saintifik. Hasil tes yang dilakukan menunjukkan seberapa besar kemampuan siswa dalam meenyimak materi mengenai tema 5 Pahlawanku, subtema 1 Perjuangan Para Pahlawanku.

Setelah dilakukannya tes didapatlah hasil bahwa dari 29 siswa yang mengikuti tes terdapat dua siswa $(7 \%)$ yang meraih nilai psikomotor kisaran 85-100 (Peringkat A), empat belas siswa (48\%) yang meraih nilai psikomotor kisaran 70-84 (Peringkat B), dua siswa $(7 \%)$ yang meraih nilai psikomotor kisaran 55-69 (Peringkat C), dan sebelas siswa $(38 \%)$ yang meraih nilai psikomotor kurang dari 55 (Peringkat D). Apabila dirataratakan maka keseluruhan siswa mendapat nilai rata-rata sebesar 61.6.

Hasil penelitian untuk setiap aspek penilaian psikomotor menunjukkan bahwa, aspek topik cerita meraih nilai keberhasil sebesar 68 (cukup), aspek alur cerita meraih nilai keberhasilan sebesar 62 (cukup), aspek ejaan memiliki nilai sebesar 61 (cukup), aspek fakta pendukung meraih nilai sebesar 60 (cukup), aspek kesesuaian isi meraih nilai 64 (cukup), aspek bahasa meraih nilai sebesar 40 (kurang), dan aspek penyajian meraih nilai sebesar 68 (cukup). Hasil tersebut menggambarkan bahwa masih rendahnya pencapaian yang didapatkan oleh peserta didik pada ranah psikomotor

\section{SIKLUS II}

Setalah terlaksananya kegiatan penelitian siklus II yakni terhitung empat pertemuan, yang dimulai pada hari Selasa tanggal 31 januari 2017 sampai dengan har 2. Selasa tanggal 9 Februari 2017 dengan tema Pahlawanku, subtema Pahlawanku Kebanggaanku, banyak hal yang telah diamati selama penelitian. Aspek yang diamati mencakup aspek ranah kognitif, dan psikomotor.
Berdasarkan hasil penilaian yang dilakukan oleh observer (Jamsiah,S.Pd) terhadap peneliti sebagai pendidik dalam pembelajaran Bahasa Indonesia yang dilaksanakan selama siklus II aktivitas pembelajaran yang dilakukan oleh peneliti sebagai pendidik mendapatkan nilai dengan persentasi $83 \%$.

Sementara untuk hasil pengamatan yang dilakukan oleh observer (Jamsiah, S.Pd) terhadap peserta didik dalam pembalajaran Bahasa Indonesia yang dilaksanakan selama siklus II, aktivitas pembelajaran yang dilakukan oleh peserta didik mendapatkan nilai dengan presentasi $80.4 \%$.

\section{Ranah Kognitif}

Melihat daftar nilai pada table hasil tes kognitif pada siklus II, terdapat 29 siswa yang mengikuti tes, terdapat sebelas siswa (39\%) yang meraih nilai kisaran 85-100 (Peringkat A), enam belas siswa (54\%) yang meraih nilai kisaran 70-84 (Peringkat B), satu siswa (3.5\%) yang meraih nilai kisaran 55-69 (Peringkat C), dan satu siswa $(3.5 \%)$ yang meraih nilai kurang dari 55 (Peringkat D). Berikut ini adalah tabel perbandingan untuk memperjelas hasil belajar yang diraih siswa pada siklus II.

Tabel 4.4 perbandingan hasil belajar siklus II

$\begin{array}{ccc}\text { Hasil } & \begin{array}{c}\text { Banyak } \\ \text { Peserta } \\ \text { Didik }\end{array} & \text { Presentase } \\ & \end{array}$

\begin{tabular}{ccc}
\hline Tuntas & 27 & $93 \%$ \\
\hline $\begin{array}{c}\text { Belum } \\
\text { Tuntas }\end{array}$ & 2 & $7 \%$ \\
\hline
\end{tabular}

$\begin{array}{lll}\text { Jumlah } \quad 29 & 100 \%\end{array}$


menggunakan pendekatan saintifik. Hasil tes yang dilakukan menunjukkan seberapa besar kemampuan siswa dalam meenyimak materi mengenai tema 5 Pahlawanku, subtema 2 Pahlawanku Kebanggaanku.

Setelah dilakukannya tes didapatlah hasil bahwa dari 29 siswa yang mengikuti tes terdapat sebelas siswa (39\%) yang meraih nilai kisaran 85-100 (Peringkat A), enam belas siswa (54\%) yang meraih nilai kisaran 70-84 (Peringkat B), satu siswa (3.5\%) yang meraih nilai kisaran 55-69 (Peringkat C). dan satu siswa $(3.5 \%)$ vang pada akhir siklus, dan peningkatan pada ranah psikomotor yang dibuktikan melalui hasil pengamatan penilaian psikomotor selama sikllus berlangsung

\section{Ranah Kognitif}

Peningkatan

keterampilan menyimak pada ranah kognitif dilakukan melaui penilaian hasil belajar siswa yang dilakukan pada setiap akhir siklus. Berikut ini tabel perbandingan hasil penilaian ranah kognitif yang menunjukkan terjadinya peningkatan keterampilan menyimak.

Tahel 4.5 Perhandingan

Meningkatkan Keterampilan Menyimak Melalui Pendekatan Saintifik Pada Anak Kelas IV Jakarta Barat

Hasil penelitian untuk setiap aspek penilaian psikomotor menunjukkan bahwa, aspek topik cerita meraih nilai keberhasil sebesar 92 (amat baik), aspek alur cerita meraih nilai keberhasilan sebesar 77.5 (baik), aspek ejaan memiliki nilai sebesar 75 (baik), aspek fakta pendukung meraih nilai sebesar 84 (baik), aspek kesesuaian isi meraih nilai 92 (amat baik), aspek bahasa meraih nilai sebesar 72 (cukup), dan aspek penyajian meraih nilai sebesar 78 (baik). Apabila dirata-ratakan maka rata-rata tingkat ketercapaian masing-masing aspek adalah 81.5. Hasil tersebut menggambarkan bahwa pencapaian yang didapatkan oleh peserta didik pada ranah psikomotor telah memenuhi harapan dan target

\section{PEMBAHASAN}

Berdasarkan hasil penelitian yang telah dilakukan untuk meningkatkan keterampilan menyimak melalui pendekatan saintifik pada siswa kelas IV SDN 01 Pagi Mangga Besar dengan materi pada tema 5 Pahlawanku, subtema 1 Perjuangan Para Pahlawan dan subtema 2 Pahlawanku Kebangaanku terdapat peningkatan yang signifikan. Peningkatan keterampilan menyimak pada pembelajaran Bahasa Indoesia dinilai dari beberapa aspek yakni, peningkatan pada ranah kognitif yang dibuktikan melalui hasil tes yang diberikan

\begin{tabular}{lllll}
\hline $\begin{array}{c}\text { KETUNT } \\
\text { ASAN }\end{array}$ & $\begin{array}{c}\text { SIKL } \\
\text { US I }\end{array}$ & $\begin{array}{c}\text { SIKL } \\
\text { US II }\end{array}$ & $\begin{array}{c}\% \\
\text { SIKL } \\
\text { US I }\end{array}$ & $\begin{array}{c}\% \\
\text { SIKL } \\
\text { US II }\end{array}$ \\
\hline TUNTAS & 16 & 27 & $55 \%$ & $93 \%$ \\
\hline TIDAK & 13 & 2 & $45 \%$ & $7 \%$ \\
TUNTAS & & & & \\
\hline JUMLAH & 29 & 29 & $100 \%$ & $100 \%$ \\
\hline
\end{tabular}

Berdasarkan hasil penilaian pembelajaran bahasa Indonesia dalam upaya meningkatkan keterampilan menyimak peserta didik kelas IV SDN Mangga Besar 01 Pagi, terdapat 29 peserta didk yang menjalani tes pada siklus I dengan rincian, dua siswa (7\%) yang meraih nilai kisaran 85-100 (Peringkat A), empat belas siswa (48\%) yang meraih nilai kisaran 70-84 (Peringkat B), dua siswa (7\%) yang meraih nilai kisaran 55-69 (Peringkat C), dan sebelas siswa (38\%) yang meraih nilai kurang dari 55 (Peringkat D). Apabila dirata-ratakan maka keseluruhan siswa mendapat nilai rata-rata sebesar 60.5. adapun nilai rata-rata yang diperoleh belum mencapai nilai KKM maka penelitian dilanjutkan pada siklus II.

Sedangkan pada siklus II didapatkan hasil dari 29 peserta didik yang menjalani tes terdapat sebelas siswa (39\%) yang meraih nilai kisaran 85-100 (Peringkat A), enam belas siswa (54\%) yang meraih nilai kisaran 70-84 (Peringkat B), satu siswa 
(3.5\%) yang meraih nilai kisaran 55-69 (Peringkat C), dan satu siswa $(3.5 \%)$ yang meraih nilai kurang dari 55 (Peringkat D). Apabila dirata-ratakan maka keseluruhan siswa mendapat nilai rata-rata sebesar 79.6.

\section{Ranah Psikomotor}

Peningkatan

menyimak pada ranah psikomotor dilakukan melaui penilaian identifikasi aspek-aaspek menyimak. Penilaian keerampilan menyimak siswa yang dilakukan pada setiap akhir siklus. Berikut ini tabel perbandingan hasil penilaian ranah psikomotor yang menunjukkan terjadinya peningkatan keterampilan menyimak.

Tabel 4. 6

Hasil Menyimak Keterampilan Psikomotor

\begin{tabular}{cccc}
\hline No & Kriteria & $\begin{array}{c}\text { Siklus } \\
\text { I }\end{array}$ & $\begin{array}{c}\text { Siklus } \\
\text { II }\end{array}$ \\
\hline $\mathbf{1}$ & Topik cerita & 68 & 92 \\
\hline $\mathbf{2}$ & Alur cerita & 62 & 77 \\
\hline $\mathbf{3}$ & Ejaan & 61 & 75 \\
\hline $\mathbf{4}$ & Fakta & 64 & 84 \\
& Pendukung & & \\
\hline $\mathbf{5}$ & Kesesuaian isi & 40 & 92 \\
\hline $\mathbf{6}$ & Bahasa & 68 & 72 \\
\hline $\mathbf{7}$ & Penyajian & 60 & 78 \\
\hline$\quad$ Rata-rata & 60,4 & 81,4
\end{tabular}

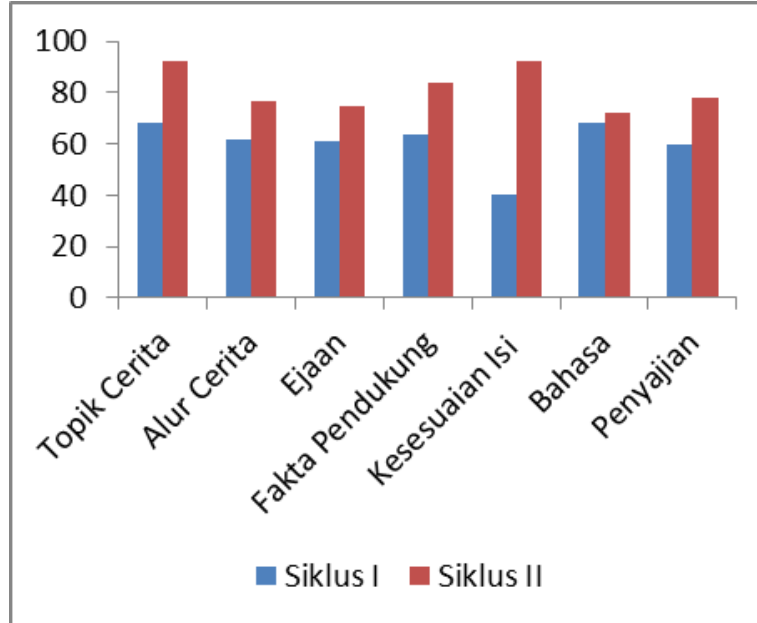

Grafik Kemajuan

Keterampilan Menyimak Setiap Siklus

Hasil penelitian untuk setiap aspek penilaian psikomotor menunjukkan bahwa, aspek topik cerita meraih nilai keberhasil sebesar 68 (cukup), aspek alur cerita meraih nilai keberhasilan sebesar 62(cukup), aspek ejaan memiliki nilai sebesar 61 (cukup), aspek fakta pendukung meraih nilai sebesar (cukup), aspek kesesuaian isi meraih nilai 64 (cukup), aspek bahasa meraih nilai sebesar 40 (kurang), dan aspek penyajian meraih nilai sebesar 68 (cukup). Apabila dirataratakan maka rata-rata tingkat ketercapaian masing-masing aspek adalah 60.4. Hasil tersebut menggambarkan bahwa masih rendahnya pencapaian yang didapatkan oleh peserta didikpada ranah psikomotor. Berikut ini adalah tabel perbandingan untuk memperjelas hasil belajar yang diraih siswa pada siklus I

Sedangkan pada siklus II Hasil penelitian untuk setiap aspek penilaian psikomotor menunjukkan bahwa, aspek topik cerita meraih nilai keberhasil sebesar 92 (amat baik), aspek alur cerita meraih nilai keberhasilan sebesar 77.5 (baik), aspek ejaan memiliki nilai sebesar 75 (baik), aspek fakta pendukung meraih nilai sebesar 84 (baik), aspek kesesuaian isi meraih nilai 92 (amat baik), aspek bahasa meraih nilai sebesar 72 (cukup), dan aspek penyajian meraih nilai sebesar 78 (baik). Apabila dirata-ratakan 
maka rata-rata tingkat ketercapaian masingmasing aspek adalah 81.5. Hasil tersebut menggambarkan bahwa pencapaian yang didapatkan oleh peserta didik pada ranah psikomotor telah memenuhi harapan dan target.

\section{SIMPULAN}

Kesimpulan dari hasil penelitian ini ialah, penggunaan pendekatan saintifik dalam meningkatkan keterampilan menyimak telah dinyatakan berhasil terhadap siswa kelas IV SDN Mangga Besar 01 Pagi, Kecamatan Taman Sari, Jakarta Barat. Terbukti pendekatan saintifik mampu untuk menciptakan pembelajaran yang aktif melibatkan siswa, dalam hal ini erat kaitannya dengan kegiatan menyimak

\section{SARAN}

Berdasarkan penelitian yang telah dilakukan, perlu ditingkatkannya kemampuanmenyimak siswa, gunakan pendekatan yang sesuai dengan siswa.

\section{DAFTAR PUSTAKA}

Arono. 2010. e-journal. Pengembangan Pembelajaran etrampilan Menyimak melalui Teknologi Informasi. Bengkulu. Universitas Bengkulu.

Daryanto.2014.Pendekatan Pembelajaran Saintifik Kurikulum 2013. Yogyakarta; Gava Med

Depdiknas, kurikulum-2013-kompetensi dasar bahasa Indonesia.

Djuanda, D. 2008. Pembelajaran Keterampilan Berbahasa Indonesia di
Sekolah Dasar. Bandung: Pustaka Latifah.

Ekawarna.2010.Penelitian Tindakan Kelas. Jakarta; Gaung Persada Press.

Harto Mohhamad, Ketut T Artha, I. 2013. Tesis: pemanfaatan media pembelajaran boneka tangan pada tema binatang terhadap peningkatan kemampuan menyimak dan berbicara anak di ra hidayatullah benowo surabaya. Surabaya;Universitas Negeri Surabaya

Majid Abdul \&Rocman Chaerul. 2014.Pendekatan Ilmiah dalam Implementasi Kurikulum 2013. Bandung;Remaja Rosdakarya.

Mulyati, Y. (2009). Bahasa Indonesia. Jakarta: Universitas Terbuka

Permen nomor 57 tahun 2014 tentang kurikulum 2013. Pasal 5.butir 6 Putriani Kusuma Antari, Ni Putu.dkk. 2016. e-journal. Penerapan Saintifik Melalui Bermain Peran Untuk Meningkatkan Keterampilan Bahasa Indonesia.Bali.Universitas

Pendidikan Ganesha Singaraja.

Resmini, N., Hartati, T. \& Cahyani, I. (2007). Pembinaan dan Pengembangan Bahasa dan Sastra Indonesia. Bandung: UPI PRESS. hal 35

Tarigan, H. G. (2014). Menyimak sebagai suatu Keterampilan Berbahasa. Bandung: Angkasa Bandung.

Zulelas.2011.Disertasi:Peningkatan

Keterampilan Menulis Narasi Melalui Pendekatan Kontruktuvisme. Jakarta;Universitas Negeri Jakarta 